\title{
Influence Analysis of Computer Modular Learning Environment on College English Listening Teaching Effect
}

\author{
https://doi.org/10.3991/ijet.v13i04.8476 \\ Jun Miao, Lidan Mao $\left.{ }^{(}\right)$ \\ Agriculture University of Hebei, Baoding, China \\ mia_mao@163.com
}

\begin{abstract}
The listening teaching incorporated with computer web-based learning platform technology, has offered the opportunity for English listening teaching. This paper firstly introduces the web-based teaching platform development and related technologies, selects the Moodle platform as the on-line platform, and then designs the teaching experiment of college English listening on the basis of this platform. In the experiment, this paper, taking the 128 non-English major students of one university in China as object of study, conducts the contrast experiment between the Moodle-based listening teaching and traditional listening teaching, and makes statistical analysis of the experimental results by the questionnaire survey as well as the pre-experiment and after-experiment methods. The study in this paper promotes the application of web-based teaching platform in English listening teaching, and has positive effects on promoting the students' learning enthusiasm and listening education reform.
\end{abstract}

Keywords-Modular Object-Oriented Dynamic Learning Environment (Moodle) platform; listening teaching; contrast experiment; education reform

\section{$1 \quad$ Introduction}

In College English Curriculum Requirements of Ministry of Education, it states clearly that the English teaching in China should emphasize on the application of Informaionization technology in English teaching, and change the traditional English teaching model; it is expected to shift the teacher-centred English teaching model to student-centred model, improving the students' enthusiasm and involvement in the English learning. The English listening is always one weak part of college students' English skills in China; it is of important significance to enhance their English listening level, because English listening is not only the main part of English learning, but also plays an important role in their future work and social communications [1]. With the deeper integration of computer technology and college English education, application of computer multi-media aided technology in the English listening teaching, esp. the web-based platform technology, has become the evitable trend. 
The applied researches on computer-aided technology and computer web-based teaching in English listening teaching have made certain achievements [2]. Some foreign scholar, in their study of listening teaching in computer multi-media environment, compared the audio and video materials by the three media (incl. paper and pen), and the accuracy of comprehensive understanding test and cloze tests in multi-media environment, finding that the listening scores had been promoted greatly [3]; the domestic scholars conducted the researches on the computer-assisted English listening teaching, putting forward that the MCALL network software-based English teaching was the development trend; some other scholars insisted that the web-based autonomous learning mode was the development trend of English teaching [4]. Although these researches at home and abroad on English learning have been rather intensive, they were mainly focuses on the teaching model and learning strategy for the students, and in lack of empirical study for college English teaching. Besides, few research was made on the application of specific English on-line learning platform in English listening teaching, based on the teaching demand [5].

Selecting the Moodle platform for English listening teaching, this paper analyses its function in the different phases of English listening learning, including preparation phase, cognitive phase, and evaluation phase, and then designs the teaching experiment after reviewing the related theories of English listening learning [6]. In the one-semester teaching experiment, by taking the 128 students of non-English majors in Grade 2 of one university, divide the students into two groups: contrast group and experimental group, and make pre-experiment and after-experiment exam to analyse the teaching effect of English listening. In this paper, the specific network teaching platform was applied and validated in the practical teaching case; the experiment results are of vital importance for guiding the selection of English listening teaching web-based platform and promoting its application in the English listening.

\section{On-line course platform and related learning theory}

\subsection{On-line course platform}

Modular Object-Oriented Dynamic Learning Environment (Moodle) is an on-line course platform based on open source software. It follows the principle of mutual equality between the educator and learner, aiming to fully booster their collaborative relationship in the teaching activity. It offers smooth network environment for users with the clear operation interface, teaching course management and teaching activity scheduling for the teachers, and the free learning environment for the students [7].

The Moodle platform, as the communication bridge between the teachers and students, can offer better teaching and on-line learning virtual environment. The different function modules could facilitate the students to make autonomous inquiry learning and collaborative learning, gaining the course-related scientific knowledge as well as cultivating stronger ability. In addition, it has no high requirement for the learners' computer skill; only with basic computer operation skill and use of browser, the learners can access to the platform easily [8]. 


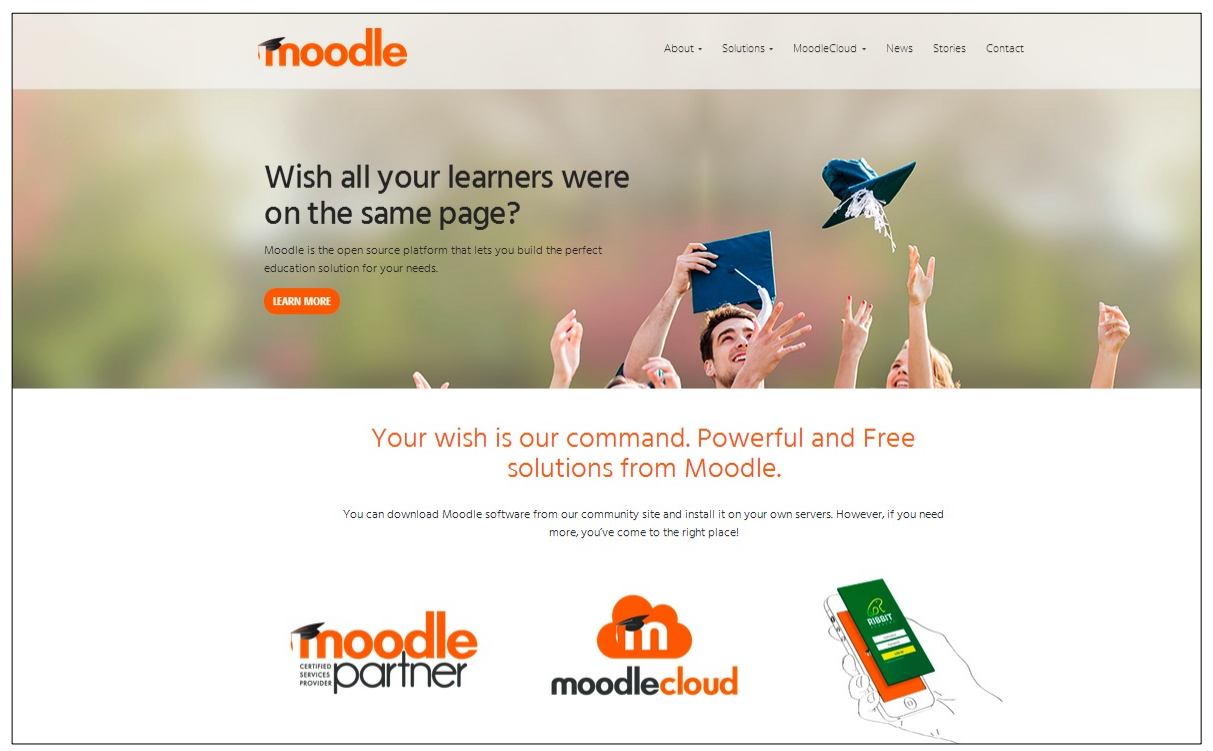

Fig. 1. The screenshots of Moodle platform

Now the globally widely-applied web-based learning platform includes Bodington, Blackboard, and Moodle etc. The Moodle platform has been selected, because it has function of multi-lingual support such as simplified Chinese etc, is completely free, and can be updated in the open source condition by the Moodle fans all over the world [9]. Moodle platform has strong on-line teaching functions: (1) Multi-type courses support; (2) Flexible course offering; (3) Trace analysis of learning records; (4) Class and group function; (5) Course resource management; (6) Two evaluation methods of fractional system and grading system support available; (7) Test question database function, including the independent question database for every course; (8) Multi-online-teaching modules support; (9) On-line learning industrial standard support, such as IMS, SCORM, and QTI. Based on these functions and features above, this paper applies the Moodle platform in college English teaching course.

Fig 1 depicts the screenshot of Moodle online learning platform, which can offer a transparent operation way for English learning.

\subsection{Related learning theory}

The application of Moodle platform in English listening teaching needs related learning theory, which can provide guidance to realize the best teaching effect.

Constructivism learning theory. The constructivism learning theory mainly consists of three points: 1 . Learning process is the reconstruction of the original cognitive structure for the learners according to their own interests; 2. Constructivists emphasizes on the importance of "context" for learning, thinking that the learning environment plays a key role in learning effect; 3 . The constructivism insists that the student 
is the dominant part in learning and cognitive behaviour; only by improve their cognitive capacity, their learning skill can be enhanced [10].

Schema theory. The schema theory is the summarization and distillation of schematic knowledge applied in the cognitive practice. In the Moodle platform-based college English listening teaching, the platform supports the uploading and management of different files such as documents, audio and video etc., so the teacher should pay more attention to the linguistic schema, content schema and formal schema, and present more background knowledge, for the students to facilitate the language acquisition from the cultural perspective, and experience the applications of language in the specific context.

Listening theory. Listening consists of automatic speech recognition and speech understanding. The speech understanding can be divided into 3 stages: perceptual processing, parsing, and utilization stage. At perceptual processing stage, the listener saves the voice in the short-term memory; at parsing stage, the listener parses the short-memory into the linguistic units of sentence, phrase and word etc, to be saved as long-term memory. At utilization stage, the listener links his own knowledge with the saved memory, to make correct understanding of the listening material [11].

The influencing factors on the listening level includes subjective factor and objective factor. The subjective factors mean those related directly to the listener, such as language knowledge, background knowledge, listening competence and emotive factor; the external factor received by the listener passively is also called as objective factor, mainly including the pronunciation and tone of listening material, background noise, recording and environmental noise etc.

In light of the related learning theory above, this paper conducts the design of the teaching activity for college students' English listening based on Moodle platform.

\section{Application of Moodle platform in college English listening teaching}

\subsection{Application of Moodle platform in college English listening teaching}

Generally, listening is divided into 3 phases: pre-listening preparation, in-listening, and post-listening.

Pre-listening phase. In pre-listening preparation phase, the teacher should help the students to narrow down the estimated listening material, and reduce their burden of listening learning.

In-listening phase. In this phase, the teacher enables the students to learn about the language knowledge such as pronunciation, grammar and vocabulary via class activity. Moodle platform can make uploading and management of multi-format files such as .doc and .ppt etc., and the management of audio and video materials; by integration of these resources, it can develop one course, in which different contents can be uploaded in the Moodle system, for the continuation an improvement of teaching class [12]. In view of variety with the students' English level, the cooperative group is adopted to ensure every student can be improved in different degree; also, different 
forms of interaction are applied, including questioning, discussion, performance, retell and dictation. Fig 2 shows the interface of Moodle platform about the students' listening training.

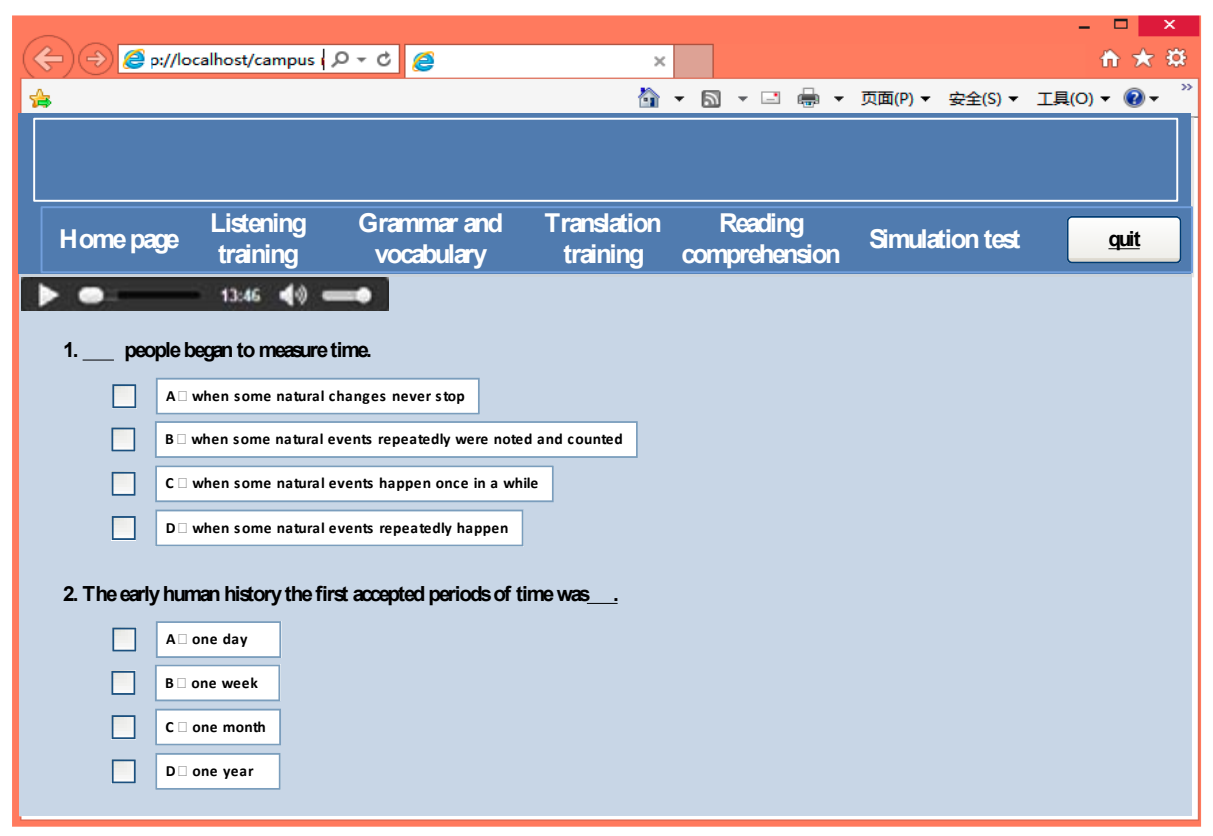

Fig. 2. The interface of listening training

Post-listening evaluation phase. In post-listening evaluation phase, the memory is consolidated. Moodle platform functions as discussion area, where the teacher checks whether the listening teaching reaches the expected effects by communicating with the students. Through the comprehensive analysis of the listening material, the students can further understand the meaning of the listening material [13].

\subsection{Moodle platform-based teaching design of college English listening}

\section{Basic requirements for Moodle platform-based listening teaching.}

1. Moodle provides sufficient and individualized communication platform for students, not only the computer network learning.

2. On the platform, the teacher arranges the students to take autonomous learning, and solve their questions in time.

3. The teacher follows on the students' learning schedule, and offers individualized assistance, with Moodle as the teaching evaluation and monitoring platform.

4. It helps the students to realize the transformation from language knowledge to language competence. 


\section{Teaching analysis .}

1. Analysis of the students: the learning motivation of the learners is mostly to improve their subject-specific achievements, pass the CFT-4 and CFT-6 Exam, and promote their English competence; before the platform-based learning, the students have probably grasped the basic pronunciation and grammar with about 1,800 vocabulary, and has preliminary training ability to listen, speak, read and write; regarding the computer level, they have reached the Level 2 computer operation, and often make communication in the network environment, being capable of visiting the Moodle platform freely [14].

2. Analysis of teaching content: the Twenty-first Century College English published by Fudan University was used as teaching material, which consists of 8 units; communication skill, listening strategy and extensive listening is the main training objectives.

3. Analysis of teaching objective: the ability training objectives of college English listening teaching was mainly enabling the students to distinguish the liaison and stress, tell apart the sentence structures, understand the implied meanings of different sentence structure, and judge the grammatical mood; to get familiar with features of the oral language is for the students to measure the topic sentence, fill the missing information in the context, combine the listening content with the reality for understanding the speaker's intension.

Teaching implementation. Moodle platform supports the teaching models of teaching-receptive, research-project, and community-group, including three stages for teaching implementation: student class-selection, course learning and teaching process. At the class selection stage, the students browse the course list, select the course and then wait for the approval of Moodle platform; at the course learning stage, the teacher approves the course application on the platform, and then manage the students; at the teaching process stage, it includes review before class, in-class teaching and discussion after class [15].

\section{Moodle platform-based teaching experiment of college English listening}

\subsection{Teaching experiment design}

To validate the application effect of Moodle platform in college English listening, this paper selected 128 non-English major students of one University in China, and conducted one-semester teaching experimental study. In the experiment, the exam and questionnaire survey were adopted; the survey information and exam data of the experimental group and contrast group were collected and calculated.

Objective of teaching experiment. This experiment is designed to solve the following two questions: 
1. Whether can the platformed-based college English listening teaching greatly improve the learner's English level?

2. What attitudes does the students take towards the platform-based college English listening teaching?

Subject of experiment. By taking 128 non-English major college students in Grade 2 as subject of experiment, in the pre-experiment exam, their scores of these students had no significant difference, indicating that they were at the same level of English listening at the beginning of experiment. Class 1, 65 students was selected as experimental class, applying the Moodle-based listening teaching; Class 2, 63 students, as the contrast group, still followed the traditional English listening teaching.

Experiment tools. The model test 4 and model test 5 in college listening exam database system of CFT-4 were used as the pre-experiment paper and after-experiment paper respectively, with 35 total points, including 15 short conversations, 10 long dialogues, and 1 compound dictation. The scores of the exams were calculated by SPSS 11.5.

Experiment process. The teaching period was 16 weeks, with the listening teaching of 1 class hour every week. For the experimental class, the students should take one class hour of Moodle platform-based autonomous listening learning evert two weeks, and at least one class hour of online learning on the Moodle platform after class; in the contrast class, the students take 2 class hours of listening learning, by the mode of traditional typescript dictation and teacher explanation.

\subsection{Experiment results and analysis}

Questionnaire survey of students' attitude.

Satisfaction for Moodle-based listening learning. In terms of the general feeling for this learning mode, $13 \%$ students like very much, and $76 \%$ like; in terms of the suitability, $11 \%$ students choose "very suitable", and $60 \%$ choose to be "suitable".

It indicates that most students are satisfied about the Moodle platform-based on-line listening teaching mode after one-semester training.

Moodle-based teaching learning effect. Over 74\% students are satisfied about the teaching effect of Moodle platform-based listening, and over $84 \%$ prefer continuing this learning mode next semester to improve their own English listening level.

Statistic analysis of the students' listening scores. SPSS was applied to calculate the pre-experiment and after-experiment scores of these classes, and then independent sample test $\mathrm{T}$ was made; the results are shown in Table 1 and 2.

Table 1. Group statistics

\begin{tabular}{|l|l|c|c|c|c|}
\hline \multicolumn{2}{|c|}{ Moodle } & N & Mean & Std.Deviation & Std.Error Mean \\
\hline \multirow{2}{*}{ pretesting } & Test group & 65 & 21.85 & 4.838 & 0.600 \\
\cline { 2 - 6 } & Control group & 63 & 21.94 & 4.836 & 0.609 \\
\hline \multirow{2}{*}{ aftertest } & Test group & 65 & 24.40 & 4.510 & 0.559 \\
\cline { 2 - 6 } & Control group & 63 & 22.14 & 4.721 & 0.595 \\
\hline
\end{tabular}


It can be seen in the tables that the average pre-experiment scores in the experiment class and contrast class are 21.85 and 21.94 respectively, 0.09 more in contrast class, with no significant difference. The $T$ test shows no significant difference between these two classes $(\mathrm{P}=0.916>0.05)$, but the average after-experiment score is 24.40 in experiment class, and 22.14 in contrast class, indicating the significant difference in after-experiment exam by $\mathrm{T}$ test. Above all, compared with the traditional listening teaching, the Moodle platform-based listening teaching can better improve the students' English level.

To validate the conclusion above that the Students' English score improvement results from Moodle teaching platform, the paired sample test was taken to analysis the pre-and-after experiment scores in these two classes and then make paired comparison. The results were concluded in Table 3 and 4.

Table 2. Independent samples test

\begin{tabular}{|c|c|c|c|c|c|c|c|c|c|c|}
\hline \multirow{3}{*}{\multicolumn{2}{|c|}{ Differentiate }} & \multicolumn{2}{|c|}{$\begin{array}{l}\text { Levene s test for } \\
\text { equality of } \\
\text { variances }\end{array}$} & \multicolumn{7}{|c|}{ t-test for equality of Means } \\
\hline & & \multirow[t]{2}{*}{$\mathrm{F}$} & \multirow[t]{2}{*}{ Sig. } & \multirow[t]{2}{*}{$t$} & \multirow[t]{2}{*}{ df } & \multirow[t]{2}{*}{$\begin{array}{l}\text { Sig.(2- } \\
\text { tailed) }\end{array}$} & \multirow[t]{2}{*}{$\begin{array}{c}\text { Mean } \\
\text { Difference }\end{array}$} & \multirow[t]{2}{*}{$\begin{array}{l}\text { Std.Error } \\
\text { Differece }\end{array}$} & \multicolumn{2}{|c|}{$\begin{array}{c}95 \% \text { confidence } \\
\text { interval of the } \\
\text { difference }\end{array}$} \\
\hline & & & & & & & & & Lower & Uppe: \\
\hline \multirow{4}{*}{ pretesting } & Equal & & & & & & & & & \\
\hline & variances & & & -.106 & 126 & .916 & -.09 & .855 & -1.783 & 1.602 \\
\hline & $\begin{array}{c}\text { assumed } \\
\text { Equal }\end{array}$ & 0.000 & 0.988 & & & & & & & \\
\hline & $\begin{array}{c}\text { variances not } \\
\text { assumed }\end{array}$ & & & -.106 & 125.880 & .916 & -.09 & .855 & -1.783 & 1.062 \\
\hline \multirow{4}{*}{ aftertest } & Equal & & & & & & & & & \\
\hline & variances & & & 2.766 & 126 & .007 & 2.26 & .816 & .643 & 3.872 \\
\hline & $\begin{array}{c}\text { assumed } \\
\text { Equal }\end{array}$ & 0.506 & 0.478 & & & & & & & \\
\hline & $\begin{array}{c}\text { variances not } \\
\text { assumed }\end{array}$ & & & 2.765 & 125.254 & .007 & 2.26 & .816 & .641 & 3.873 \\
\hline
\end{tabular}

Table 3. Test group Paired samples test

\begin{tabular}{|c|c|c|c|c|c|c|c|c|c|}
\hline \multirow{3}{*}{\multicolumn{2}{|c|}{ Differentiate }} & \multicolumn{5}{|c|}{ Paired differences } & \multirow{3}{*}{$\mathrm{t}$} & \multirow{3}{*}{ df } & \multirow{3}{*}{ Sig.(2-tailed) } \\
\hline & & \multirow{2}{*}{ Mean } & \multirow[t]{2}{*}{$\begin{array}{c}\text { Std. } \\
\text { Deviation }\end{array}$} & \multirow{2}{*}{$\begin{array}{l}\text { Std. } \\
\text { Error } \\
\text { Mean }\end{array}$} & \multicolumn{2}{|c|}{$\begin{array}{l}95 \% \text { confidence } \\
\text { interval of } \\
\text { differecne }\end{array}$} & & & \\
\hline & & & & & $\begin{array}{l}\text { low } \\
\text { er }\end{array}$ & $\begin{array}{l}\text { upp } \\
\text { er }\end{array}$ & & & \\
\hline Pair 1 & $\begin{array}{c}\text { Pretesting- } \\
\text { aftertest }\end{array}$ & -.255 & 1.912 & .237 & -3.03 & .2 .08 & -10.767 & 64 & .000 \\
\hline
\end{tabular}


Table 4. Control group Paired samples test

\begin{tabular}{|c|c|c|c|c|c|c|c|c|c|}
\hline \multirow{3}{*}{\multicolumn{2}{|c|}{ Differentiate }} & \multicolumn{5}{|c|}{ Paired differences } & \multirow{3}{*}{$t$} & \multirow{3}{*}{ df } & \multirow{3}{*}{ Sig.(2-tailed) } \\
\hline & & \multirow[t]{2}{*}{ Mean } & \multirow[t]{2}{*}{$\begin{array}{c}\text { Std. } \\
\text { Deviation }\end{array}$} & \multirow{2}{*}{$\begin{array}{l}\text { Std. } \\
\text { Error } \\
\text { Mean }\end{array}$} & \multicolumn{2}{|c|}{$\begin{array}{l}95 \% \text { confidence } \\
\text { interval of } \\
\text { differecne }\end{array}$} & & & \\
\hline & & & & & lower & upper & & & \\
\hline Pair 1 & $\begin{array}{c}\text { Pretesting- } \\
\text { aftertest }\end{array}$ & -.21 & 1.095 & .138 & -.48 & .07 & -1.496 & 62 & .140 \\
\hline
\end{tabular}

Table 3 lists the $P$ value of paired samples in the experiment class is below 0.05 , indicating Moodle platform has positive effect on the student's listening learning. Table 4 lists the $P$ value of paired samples in contrast class is over 0.05 , without significant change, to conclude that the students' English level hasn't improved, therefore, it can be determined that the improvement of English level in Experiment class results from the Moodle platform-based listening teaching.

\section{Conclusion}

Based on Moodle on-line learning platform, this paper conducts research on its teaching application in the college English listening. It first introduces the platform features, analyses the function of this platform in English listening learning, then designs the related teaching experiment of Moodle application in the English teaching, and finally validate its teaching effect in the experiment by questionnaire survey as well as the listening tests. The main conclusions are drawn as:

1. The Moodle platform plays an aided role in pre-listening, in-listening, and post-listening phase of English listening.

2. The questionnaire survey shows that the Moodle platform is popular among the students, and over $80 \%$ students prefer continuing to apply the Moodle platform for improving their English listening level.

3. The contrast analysis of listening scores in the experiment class and contrast class indicates that Moodle platform has a positive effect on English learning, leading to significant change of their listening scores.

\section{References}

[1] Ma, Y.M. (2004). The effect of different approaches to repetition strategy instruction on the listening comprehension of junior high school students in Taiwan. Journal of the Neurological Sciences, 333(Supl 1): e526.

[2] Zhang, X. (2011). Research on culture introduction and innovative personnel cultivation in college English teaching. Textile Research Journal, 85(3): 238-250.

[3] Jia, J. (2009). Csiec: A computer assisted English learning chatbot based on textual knowledge and reasoning. Knowledge-Based Systems, 22(4): 249-255. https://doi.org/10.1016/j.knosys.2008.09.001 
Paper-Influence Analysis of Computer Modular Learning Environment on College English Listen...

[4] Babaie, H. (2008). On the effects of help options in mcall programs on the listening comprehension of EFL learners. Journal of the American Chemical Society, 130(38): 12808-14.

[5] Okamura, Y., Yoshizaki, S., Katahira, K. (2006). An empirical study on teaching science to make children's everyday cognition of "the change of water state" more scientific. Radiation Research, 166(5): 224-232.

[6] Jacob, P.E. (2005). Social sciences: changing values in college. an exploratory study of the impact of college teaching. Quarterly Review of Biology, 127(4).

[7] Maciel, D.T., Soares, W., Amaral, E. (2010). Moodle platform for online tutoring during internships. Medical Education, 43(11): 1113-1114. Bollela, V.R., Grec, W., Matias, A.A. (2010). Shortening distances: A Moodle platform supports programme evaluation in internship. Medical Education, 43(11): 1114-1115.

[8] Trenas, M.A., Ramos, J., Gutierrez, E.D., Romero, S., Corbera, F. (2011). Use of a new moodle module for improving the teaching of a basic course on computer architecture. IEEE Transactions on Education, 54(2): 222-228. https://doi.org/10.1109/TE.2010.204857 $\underline{0}$

[9] Burke, K.M. (1985). Social constructivism as learning, organizational, and systems theory in international relations /. Physical Review B.

[10] Gopnik, A., Wellman, H.M. (2012). Reconstructing constructivism: Causal models, Bayesian learning mechanisms, and the theory theory. Psychological Bulletin, 138(6): 1085. https://doi.org/10.1037/a0028044

[11] Cordero-Torres, J.A., Cerdà-Vila, M., Quintana, S., Carmona-Jiménez, F. (2014). Assessment of e-learning teaching (Moodle platform) in immediate life support (ILS) by the Spanish resuscitation council (cercp). results of a satisfaction survey for course instructors. Resuscitation, 85(4): S73-S73.

[12] Zou, Q.C., Campus, H.B., University, B.O. (2006). Design and realization of the learning environment of "the multimedia application base" on the platform of moodle. Canadian Journal of Chemical Engineering, 84(3): 310-315.

[13] Chen, H., Chen, H. (2015). The influence of world English's on Chinese English and English teaching in college. Journal of Organometallic Chemistry, 192(1), 1-15.

[14] Yue, Y. (2011). The AHP model of evaluation on quality-oriented education in college english teaching. Acta Biomaterialia, 2(5): 386-388.

\section{Authors}

Jun Miao received the B.A. degree in English Major from North China University of Science and Techology in 2005. Now she is a lecturer in Foreign Language College, Agriculture University of Hebei.

Lidan Mao received the B.A. degree in English Major from JiLin University, China, in 2005, and the Master of Arts degree from the Foreign Language College, Agriculture University of Hebei, China, in 2012. Now she is a lecturer in Foreign Language College, Agriculture University of Hebei.

Article submitted 20 February 2018. Final acceptance 25 March 2018. Final version published as submitted by the authors. 